VOX PATRUM 28 (2008) t. 52

Ireneusz MILEWSKI

(Gdańsk, UG)

\title{
UPADEK PATRIARCHY ALEKSANDRYJSKIEGO DIOSKURA
}

Choć nieco uszczypliwie, to jednak trafnie jezuita W. de Vries pisał, iz wszechwładny na Wschodzie Dioskur po swym tryumfie w Efezie w $449 \mathrm{r}$. zdawał się zapomnieć, iż przychylny mu Teodozjusz II był przede wszystkim „Zwykłym śmiertelnikiem”, wieść zaś o nagłej śmierci cesarza musiała spaść na patriarchę niczym grom z jasnego nieba. Dioskur udając się na sobór w $451 \mathrm{r}$. musiał zdawać sobie sprawę, iż w obliczu zaistniałej sytuacji politycznej (jego szpiedzy donosili mu bowiem o kontaktach dworu konstantynopolitańskiego z biskupem Rzymu Leonem ${ }^{2}$ ), w wyniku czystki przeprowadzonej na dworze w Konstantynopolu, może on już nie powrócić do Aleksandrii ${ }^{3}$.

Przyczyny depozycji Dioskura oraz jego późniejsze wygnanie nie są jednak tak oczywiste, jak można by sądzić w oparciu o dotychczasową literaturę, omawiającą kontrowersje doktrynalne na Wschodzie w poł. V wieku ${ }^{4}$. Nazbyt bowiem akcentuje się w niej bezpardonowe parcie dworu cesarskiego do obalenia patriarchy, by między innymi w taki sposób uspokoić nastroje panujące w Kościołach Wschodu, nazbyt poróżnionych wskutek poczynań aleksandryjskiego patriarchy ${ }^{5}$. F. Haase twierdził nawet, iż cesarz Marcjan rozważał pozyskanie

${ }^{1}$ Por. W. De Vries, Das Konzil von Ephesus 449 eine „Räubersynode”?, OCP 41 (1975) 361; zob. też N. Russell, Cyril of Alexandria, London - New York 2000, 60.

${ }^{2}$ Cesarz Marcjan w jednym ze swoich listów proponował nawet Leonowi przewodzenie obradom planowanego soboru, por. Leo Magnus, Epistula 76, PL 54, 903-906; por. także De Vries, Das Konzil von Ephesus, s. 366. Leon pozostawał wówczas również w żywym kontakcie z dworem w Rawennie, zob. Leo Magnus, Epistulae 55-57, PL 54, 857-864.

${ }^{3}$ Por. Theopistus, Vita Dioscuri 250, ed. F. Nau: Histoire de Dioscore, patriarche d'Alexandrie, écrite par son disciple Théopiste, „Journal Asiatique” 1 (1903) 1-108 (tekst), 240-310 (przekład); F. Haase, Patriarch Dioscur I. von Alexandrien. Nach monophysitischen Quellen, Breslau 1908, 204. W takim przypuszczeniu ugruntował go również fakt, iż nowy cesarz jesienią 450 r. odwołał biskupów skazanych na wygnanie po II Soborze Efeskim, por. ACO II 3, s. 19.

${ }_{4}$ Tak samo zwodnicze mogą być stwierdzenia, jakie odnajdujemy w ówczesnych relacjach źródłowych, jak chociażby to, iż sobór do Chalcedonu zwołano, by rozprawić się z „Aleksandryjczykiem” czy też „faraonem”, jak to czasami ironicznie nazywano wówczas aleksandryjskich patriarchów, por. ACO II I, 1, s. 143. 
Dioskura dla zaprowadzenia „pokoju kościelnego” na Wschodzie ${ }^{6}$. Jak się wydaje, z powodu nie do końca jasnych zamiarów Marcjana wobec Dioskura, urzędnicy cesarscy nadzorujący przebieg soboru sprzeciwili się, by oskarżycielami patriarchy byli legaci biskupa rzymskiego ${ }^{7}$. Analizując rozwój wydarzeń, poprzedzających zwołanie Soboru Chalcedońskiego, można by nawet stwierdzić, iż to biskupowi rzymskiemu najbardziej zależało na obaleniu potężnego patriarchy, propagującego odmienny dogmat chrystologiczny, a Leon jeszcze przed obaleniem patriarchy nakazał wykreślenie z dyptychów Kościoła rzymskiego Dioskura, Juwenalisa - biskupa Jerozolimy oraz Eustacjusza - biskupa Berytos $^{8}$. Znany nam materiał źródłowy nie pozwala jednak na jednoznaczne stwierdzenie, jak daleko sięgały wówczas plany biskupa Leona w związku z przewidywanym obaleniem aleksandryjskiego patriarchy. Niemniej jednak wraz z depozycją Dioskura i jego stronników biskup rzymski stałby się najznamienitszą postacią ówczesnego Kościoła. Jak się jednak okazało, rozwój wypadków tylko częściowo zaspokoił ambicje Leona; z jednej strony bowiem obalono tylko Dioskura, z drugiej zaś nad Italią pogrążoną w kryzysie politycznym (po śmierci Walentyniana III) zawisło zagrożenie ze strony barbarzyńców. Wydarzenia te, jeśli nie pokrzyżowały, to na pewno nie ułatwiły planów ekspansji politycznych wpływów biskupa rzymskiego w Kościołach Wschodu.

Mimo, iż obalenie Dioskura było decyzją polityczną, to jednak procedurę depozycyjną w jego sprawie wszczęto w oparciu o konkretne zarzuty. Przede wszystkim patriarsze wytykano jego postępowanie na Soborze Efeskim w 449 r. ${ }^{9}$, zignorowanie stanowiska biskupa rzymskiego wobec rozpatrywanych tam kwestii ${ }^{10}$, przeprowadzenie kontrowersyjnych depozycji oraz przyczynienie się do

${ }^{5}$ Por. V.C. Samuel, Proceedings of the Council of Chalcedon and its Historical Problems, .Ecumenical Review” 22 (1970) 342.

${ }^{6}$ Por. Haase, Patriarch Dioscur, s. 217 oraz s. 209-210, gdzie autor stwierdza, iż obrady w Chalcedonie, pierwotnie mające się odbyć w Nicei, poprzedził konstantynopolitański synod Endemousa, którego celem było wysondowanie nastrojów pomiędzy biskupami przed planowanymi zmianami, przede wszystkim jednak przed możliwym obaleniem patriarchy Dioskura; zob. także S.O. Horn, Petrou Kathedra. Der Bischof von Rom und die Synoden von Ephesus (449) und Chalcedon, Paderborn 1982, 189.

7 Por. ACO II 1, 1, s. 66; II 3, 1, s. 40; zob. także De Vries, Das Konzil von Ephesus, s. 380-381; Horn, Petrou Kathedra, s. 147; S. Bralewski, Imperatorzy późnego cesarstwa rzymskiego wobec zgromadzeń biskupów, Łódź 1997, 64.

8 Por. Leo Magnus, Epistula 95, 3, PL 54, 944.

9 Mimo, iz Teodozjusz II powierzył Dioskurowi przewodniczenie soborowym obradom w Efezie w 449 r. (por. ACO II I, 1, s. 69; Horn, Petrou Kathedra, s. 72-74), to jednak zgromadzeni w Chalcedonie biskupi utrzymywali, iż patriarcha przejął to przewodnictwo w drodze zamachu.

${ }^{10}$ Por. ACO II 1, 1, s. 83; II 1, 2, s. $41 \mathrm{nn}$; II 3, 2, s. 46; II 4, s. 79; zob. także De Vries, Das Konzil von Ephesus, s. 396; Horn, Petrou Kathedra, s. 156, 193; W.H.C. Frend, The Rise of the Monophysite Movement, Cambridge 1972, s. 6. Legaci biskupa rzymskiego zwrócili się bowiem z prośbą o odczytanie zebranym listów Leona, por. ACO II 1, 1, s. 82-83. O złym potraktowaniu swych legatów w Efezie, Leon w jednym ze swych listów skarży się cesarzowi Teodozjuszowi (ACO 
śmierci Flawiana Konstantynopolitańskiego i rehabilitację Eutychesa (co było jednak dość nielogicznym zarzutem $)^{11}$. Patriarsze stawiano również zarzuty o nadużycia finansowe, poczynione przez niego w Kościele Aleksandryjskim a także o to, iż przyjął on do wspólnoty duchownych zdeponowanych w innych Kościołach $^{12}$.

Już w trakcie obrad Soboru Chalcedońskiego, przed trzecim, ostatecznym wezwaniem Dioskura przed sądzące go zgromadzenie, z poważnymi zarzutami przeciwko patriarsze wystąpiło czterech aleksandryjczyków, a mianowicie trzech tamtejszych duchownych (diakoni: Teodor i Ischyrion oraz prezbiter Atanazy) oraz bliżej nieznany nam Sofroniusz. Jako pierwszy z zarzutami wystąpił diakon Teodor, którego Dioskur (rzekomo z powodu zażyłości z jego poprzednikiem Cyrylem) na początku swych rządów biskupich w Aleksandrii wykluczył z szeregów tamtejszego kleru oraz zagroził wypędzeniem z miasta. Teodor zarzucał Dioskurowi głoszenie poglądów Orygenesa, kwestionowanie dogmatu Trójcy Świętej, wycinanie drzew w Egipcie ${ }^{13}$, nasyłanie zbrojnych band na majątki swych adwersarzy, zlecenie wielu morderstw oraz „bezwstydny tryb życia”, co, jak twierdził oskarżający, może poświadczyć wielu świadków. Swe oskarżenia pod adresem Dioskura diakon Teodor zakończył przypomnieniem, iż patriarcha dopuścił się gwałtu oraz fałszerstw w czasie efeskiego latrocinium, przyczynił się do upadku oraz śmierci Flawiana konstantynopolitańskiego oraz, że z jego polecenia z dyptychów Kościoła Aleksandryjskiego usunięto imię Leona Rzymskiego. Zapewniając zaś o swej prawdomówności Teodor stwierdzał, iż rzetelność jego zeznań potwierdzić mogą m.in. bliżej nieznani nam Agorastus, Doroteusz, Euzebiusz oraz notariusz Jan ${ }^{14}$.

Jako kolejny z zarzutami wobec patriarchy wystąpił diakon Ischyrion. Według niego Dioskur miał spieniężyć zboże, które to „pobożni cesarze” przekazali Kościołom Libii w związku z utrzymującą się tam suszą. Dioskur zamiast je rozdać między potrzebujących, sprzedał je po wysokich cenach, miejscowe zaś Kościoły nie tylko, iż nie miały z czego wspierać ubogich, to jeszcze nie posiadały mąki do wypiekania chleba eucharystycznego. Ischyrion

II 4, s. 19-21). Najpewniej z inspiracji Leona list o podobnej treści do Pulcherii, siostry Teodozjusza, skierował uczestnik tych wydarzeń, Hilary, diakon Kościoła rzymskiego, por. ACO II 4, s. 27-28.

${ }^{11}$ Por. ACO II 1, 2, s. 124; Evagrius, HE II 4. Odpowiedzialność za rehabilitację Eutychesa spadała jednak w równej mierze na Juwenalisa Jerozolimskiego oraz Talazjusza, biskupa Cezarei Kapadockiej, por. ACO II 1, 1, s. 84; zob. także Horn, Petrou Kathedra, s. 65, 74 i 157. Flawian w swym liście apelacyjnym, adresowanym do Leona Rzymskiego, zwraca przede wszystkim uwagę na to, iż Dioskur zamiast zająć się w Efezie spornymi kwestiami doktrynalnymi, niemal od razu przystąpił do rozpatrywania spraw personalnych, por. ACO II 2, 1, s. 77nn; zob. także De Vries. Das Konzil von Ephesus, s. 386nn; M. Gaddis, There Is No Crime for Those who Have Christ. Religious Violence in the Christian Roman Empire, Berkeley - Los Angeles - London 2004, 74-75.

12 Por. ACO II 3, 2, s. 342; Evagrius, HE II 4.

13 Por. m.in. uwagi: E. Wipszycka, Kościót w świecie późnego antyku, Warszawa 1994, 237.

14 Por. ACO II 3, 2, s. 287-288. 
utrzymywał również, iż Peristeria, pewna zamożna matrona z Konstantynopola, przekazała spore sumy pieniężne dla egipskich klasztorów, przytułków, ksenodochiów oraz tamtejszych ubogich. Dioskur natomiast pieniądze te przeznaczył „na niecne cele” opłacając za nie „aktorki” (prostytutki), które, jak twierdził autor oskarżenia, „tarzały się w pałacu biskupim oraz jego łaźni”. Spośród owych niewiast szczególnie złą sławą cieszyła się pewna Pansofia (zwana również Oreine), a frywolne przyśpiewki na temat stosunków łączących ją z patriarchą miały wówczas krążyć po całej Aleksandrii. Ischyriona, jak utrzymywał, spotkało również wiele przykrości ze strony patriarchy, a wszystko to rzekomo ze względu na zażyłość, jaka łączyła go z poprzednikiem Dioskura, Cyrylem. Razu pewnego, z nieznanego nam jednak powodu, patriarcha nasłał nawet na Ischyriona bandę mnichów, którzy zdewastowali jego majątek, wycięli drzewa owocowe, a resztę dobytku puścili z dymem. Również i potem jego zdewastowany już majątek był wielokrotnie pustoszony przez nasyłanych tam „ekklesiastów” na czele z nadzorcą miejscowych diakonów Piotrem oraz prezbiterem Menasem, o których to Ischyrion mówił, iż bardziej należałoby ich nazwać ,pospolitymi bandytami”, niż duchownymi. Ischyrion został w końcu pojmany przez swych prześladowców i zamknięty w „,szpitalu dla okaleczonych", gdzie rzekomo nawet tam próbowano go zgładzić. Diakon jednak ostrzeżony w porę o grożącym mu niebezpieczeństwie zdołał stamtąd zbiec, a następnie opuścił Aleksandrię. W swym oskarżeniu skierowanym przeciwko Dioskurowi Ischyrion nawiązał również do skargi diakona Teodora stwierdzając, iż wielu w Egipcie musiało przyglądać się dewastowaniu swych majątków, wycinaniu drzew w ich posiadłościach, wielu także zostało obłożonych grzywnami pieniężnymi przez patriarchę (?), jak również przegnanych z Aleksandrii. Ischyrion zarzucał ponadto Dioskurowi arianizm, patriarcha bowiem, jak twierdził, sprzeciwiał się używaniu terminu homoousios. Jak zapewniał diakon, prawdziwość jego zeznań potwierdzić mogą przywołani już w jego oskarżeniu: Agoratus, Doroteusz, Euzebiusz oraz inni świadkowie, a mianowicie bliżej nieznani nam Didion, Arpocration, Piotr oraz Gajan ${ }^{15}$.

W trakcie obrad Soboru Chalcedońskiego kolejne oskarżenie pod adresem Dioskura odczytał także prezbiter Kościoła Aleksandryjskiego Atanazy. Jak utrzymywał oskarżyciel, Dioskur krótko po objęciu tronu biskupiego w Aleksandrii, miał przejąć majątek członków rodziny swego poprzednika (nic bliższego nie wiemy jednak na ten temat), w tym m.in. dobra należące do owego diakona Atanazego oraz jego brata Piotra, którzy byli siostrzeńcami Cyryla. Ci zaś szukając pomocy w swej sprawie udali się do Konstantynopola, gdzie rzekomo za sprawą zaprzyjaźnionego z Dioskurem eunucha Chryzafiusza zostali uwięzieni. Udało im się jednak wykupić z więzienia (w międzyczasie zmarł jednak jeden z osadzonych, Piotr) za ogromną sumę 1400 funtów złota (poży-

\footnotetext{
${ }^{15}$ Por. ACO II 3, 2, s. 289-293.
} 
czoną na ten cel na wysoki procent u stołecznych bankierów), która przekazana magistrowi officiorum Nomosowi (złoto zaś w jego imieniu odbierał bliżej nie znany nam magistrianos Sewer), trafiła do, jak stwierdza autor oskarżenia, „barbarzyńskiego Chryzafiusza”. Uwolnieni, opuściwszy Konstantynopol, powrócili do Aleksandrii, ukryli się jednak na jednym z jej przedmieść. W międzyczasie zaś Dioskur miał przejąć resztę majętności wygnańców, pozostawiając ich bez środków do życia. Jak czytamy w dalszej części oskarżenia, od pozostałych członków rodziny Cyryla, jego ciotek oraz sióstr (a przypomnijmy jedna z nich była matką oskarżającego) Dioskur wycisnął również 85 funtów złota, od wdowy zaś po zmarłym w konstantynopolitańskim więzieniu Piotrze wymusił dalsze 40 funtów złota. Swe oskarżenie prezbiter Atanazy zakończył apelem do zebranych na Soborze w Chalcedonie biskupów, o pomoc w odzyskaniu owych 1400 funtów złota, jak również zapewnieniem, iż może on również świadczyć o innych przestępstwach popełnionych przez „okrutniejszego od barbarzyńców Dioskura”16.

Jako ostatni z zarzutami wobec patriarchy wystąpił Sofroniusz, świecki chrześcijanin z Aleksandrii. Jak wynika z jego relacji, pewien Makariusz, jeden z aleksandryjskich dekurionów uwiódł, a następnie również ukrył na terenie miasta jego żonę Teodotę. Kiedy sprawa wyszła na jaw, i oboje kochankowie zostali rzekomo skazani na śmierć (za dopuszczenie się cudzołóstwa), wykonaniu wyroku sprzeciwił się Dioskur, stawiając swoją wolę, jak stwierdzał to oskarżyciel, ponad prawem. Dioskur miał wtedy stwierdzić, iz to on tu stanowi prawa, „bo Egipt do niego należy”, a nie do „rządzących”. By zaś poskromić upartego Sofroniusza, Dioskur wysłał do jego majątku diakona Izydora na czele bandy miejscowych wieśniaków, którzy zdewastowali jego posiadłość; Sofroniuszowi i jego dzieciom udało się jednak w porę zbiec i ukryć w bezpiecznym miejscu.

Sofroniusz zarzucał ponadto Dioskurowi obrazę cesarskiego majestatu; patriarcha bowiem próbował przeszkodzić w ugruntowywaniu władzy przez cesarza Marcjana. Kiedy zaś dawnym zwyczajem do Aleksandrii przysłano „boskie podobizny”, a mianowicie wizerunki nowej pary cesarskiej, wówczas to Dioskur chciał przy pomocy łapówki, którą próbował wręczyć kilku miejscowym urzędnikom, doprowadzić do wywiezienia z miasta owych cesarskich podobizn. Dioskur, będąc najpewniej świadom tego, iż zmiana na tronie w Konstantynopolu stanowi również niechybną zapowiedź zmiany polityki kościelnej państwa, miał wówczas publicznie wyrażać swe niezadowolenie z faktu przejęcia tronu cesarskiego przez Marcjana; chciał bowiem, jak utrzymuje autor oskarżenia, „sam rządzić w Egipcie”. Sofroniusz potwierdzając prawdomówność swych zeznań, powoływał się na protokoły z dochodzenia (sporządzone przez trybuna i notariusza Jana), jakie w sprawie znieważenia cesarskiego majestatu przez patriarchę odbyło się w Aleksandrii ${ }^{17}$.

16 Por. ACO II 3, 2, s. 294-296.

17 Por. ACO II 3, 2, s. 297-299. 
Zebrani w Chalcedonie biskupi nie mogli jednak postawić Dioskurowi zarzutu herezji, czego domagał się jego oskarżyciel Euzebiusz, biskup Doryleum $^{18}$. Dioskura bowiem obalono jeszcze przed przyjęciem opracowanej tam nowej formuły wiary. Zastrzeżenia chrystologiczne Dioskura oraz innych biskupów Wschodu do formuły proponowanej przez Leona, miały jednak swoje kulturowe podłoże. Należy oddać rację E. Schwartzowi, który stwierdza, iż Leonowi lansującemu dogmat dwóch współdziałających ze sobą natur Chrystusa, ludzkiej i boskiej, była zupełnie obca ,istota greckiej pobożności na Wschodzie" $"$.

Analizując przebieg postępowania depozycyjnego, prowadzonego w sprawie aleksandryjskiego patriarchy, wydaje się, iż cesarz Marcjan podjął ostateczną decyzję o obaleniu Dioskura dopiero po pierwszej sesji soboru, po mającym tam miejsce wystąpieniu patriarchy, kiedy okazało się, iż nie jest on skłonny do kompromisu i że nadal wśród biskupów Wschodu istnieje ogromny sprzeciw wobec przyjęcia Tomosu Leona ${ }^{20}$. Sam zaś Dioskur na złożoną mu propozycję przyjęcia Tomosu Leona miał odpowiedzieć, iż nie podpisze go nawet wtedy „gdyby miano mu obciąć dłoń, albo też utoczyć krwi" ${ }^{21}$. Ta relacja najpewniej jednak mija się z prawdą, a w zamiarze jej propagatora miała wykazać, jak zdecydowanym przeciwnikiem lansowanego przez Leona dogmatu chrystologicznego był patriarcha aleksandryjski. Dioskur, podbudowany oporem części biskupów Wschodu wobec stanowiska biskupa rzymskiego, nie zamierzał więc poddawać się bez walki i próbował zmobilizować swych, jak mu się jeszcze wydawało, stronników. Patriarcha dalece się jednak mylił w ocenie zaistniałej sytuacji, sprzeciw bowiem wobec Tomosu Leona pomiędzy wieloma biskupami Wschodu nie oznaczał jednak, iż będą oni bronili swych poglądów za wszelką cenę, a już na pewno nie za cenę utraty tronu, tym bardziej, iz jak wynikało ze stanowiska legatów biskupa rzymskiego, przeciwnicy Dioskura skłaniali się do puszczenia w niepamięć ich uczestnictwo w knowaniach mających miejsce w czasie efeskiego latrocinium $^{22}$. Kolejna poważna rysa na partii Dioskura pojawiła się w związku z rehabilitacją Flawiana, którą poparli Juwenalis, biskupi palestyńscy, a nawet czterech biskupów egipskich ${ }^{23}$. Juwenalis, choć nieco skrępowany ko-

${ }_{18}$ Por. ACO II 1, 2, s. 9; Evagrius, HE II 4; zob. także De Vries, Das Konzil von Ephesus, s. 378; Gaddis, There Is no Crime, s. 318.

19 Por. E. Schwartz, Zur Geschichte der alten Kirche und ihres Rechts w: Gesammelte Schriften, Bd. 4, Berlin 1960, 137; Frend, The Rise of the Monophysite, s. 44.

${ }^{20}$ Por. Theopistus, Vita Dioscuri 269-271; zob. także ACO II 1, 1, 14, s. 66; Evagrius, HE II 4.

${ }^{21}$ Michael Syriacus, Chronicon II 51, ed. J.B. Chabot, Paris 1899; zob. także F. Haase, Altchristliche Kirchengeschichte nach orientalischen Quellen, Leipzig 1925, 308.

${ }^{22}$ Por. Evagrius, HE II 4.

23 Por. ACO II 1, 1, s. 111nn; zob. także P.Th. Camelot, Ephesus und Chalcedon, Mainz 1963, 140. 
niecznością odstąpienia od Dioskura, miał stwierdzić, iż z jego powodu biskupi nie mają zamiaru trafić na wygnanie ${ }^{24}$. Wedle relacji Theopista, w dość sarkastycznym tonie na próbę skonsolidowania przeciwników Tomosu Leona przez Dioskura miał zareagować Bazyli z Seleucji stwierdzając:

„Spójrzcie tylko na tych Aleksandryjczyków, którzy nie zważają ani na cesarza ani też na innych biskupów"25.

Niemniej ironicznie zareagować miał również Leoncjusz, biskup Askalonu, stwierdzając:
„Dioskur jest obrazą tego zgromadzenia, chce byśmy z jego powodu poszli na wygnanie. Ten «święty» utrzymuje, iż walczy za prawdziwą wiarę, stawia się po- nad Bogiem, tymi trzema [to znaczy ponad biskupami Rzymu, Konstantynopola oraz Antiochii - I. M.] i ponad resztę biskupów. Jeżeli jednak upadnie Aleksandria oraz Dioskur, to czy Kościół przestanie wówczas istnieć?"26.

Mimo, iż najpewniej wyżej zacytowane wypowiedzi biskupów są produktem fantazji Theopista, monofizyckiego biografa Dioskura, to jednak dyskusja na temat patriarchy prowadzona w czasie obrad soboru nieraz wymykała się biskupom spod kontroli. Nic więc dziwnego zatem, iż jeden z cesarskich wysłanników przysłuchujący się debacie, chcąc uspokoić wzburzenie obradują-

${ }^{24}$ Stanowisko biskupa Jerozolimy wobec gwałtownie zmieniającej się sytuacji przed, jak również w trakcie soboru w Chalcedonie skwitował, monofizyta Michał Syryjczyk stwierdzając, iż Juwenalis udając się na sobór utrzymywał, iż nie podpisze się pod „żydowskim Tomosem” i przestrzegał przed tym innych biskupów palestyńskich. Jednakże kiedy w trakcie obrad zaczął osuwać mu się grunt pod nogami i kiedy wyraźnie zakomunikowano mu, iż w zamian za podpisanie Tomosu oraz odstąpienie od Dioskura, jego biskupstwo zostanie wyniesione do rangi patriarchatu (o co Juwenalis bezskutecznie zabiegał już w trakcie obrad I Soboru Efeskiego), a on sam otrzyma jurysdykcję nad trzynastoma biskupstwami w Palestynie, jakie wydzielone zostaną z patriarchatu antiocheńskiego, wówczas Juwenalis opuścił stronnictwo Dioskura oraz podpisał się pod dokumentem sporządzonym przez biskupa rzymskiego, por. ACO II 2, 3, s. 5-7; Evagrius, HE II 18; P.R. Coleman-Norton, Roman State and Christian Church. A Collection of Legal Documents to A.D. 535, vol. 2, London 1966, 782; Liberatus, Breviarium 13; Michael Syriacus, Chronicon II 89; zob. także E. Honigmann, Juvenal of Jerusalem, DOP 5 (1950) 240 i 244-246; Camelot, Ephesus, s. 170nn; Horn, Petrou Kathedra, s. 145-146. Juwenalis swym odstępstwem od Dioskura nie zaskarbił sobie również sympatii innych autorów monofizyckich, przez których jest on nazywany chociażby „zdrajcą Judaszem” (Vita Petri Iberi 53) czy też „wrogiem Boga” (Theopistus, Vita Dioscuri 242). W skutek swego odstępstwa Juwenalis utracił na krótko władzę nad swym Kościołem, który opanował monofizycki mnich Teodozjusz, inni zaś monofizyci próbowali obsadzić swymi duchownymi trony tych biskupów, którzy w Chalcedonie przeszli na stronę koncyliarystów. Juwenalis bezsilny wobec zaistniałej sytuacji udał się do Konstantynopola, do cesarza Marcjana, a w $453 \mathrm{r}$. z pomocą zbrojnych oddziałów udało mu się odzyskać utracony tron, por. Evagrius, HE II 5; zob. także W. Ensslin, Marcianus (34), RE 14/2 (1930) 1524-1525; P.T.R. Gray, The Defense of Chalcedon in the East (451-553), Leiden 1979, 17-19.

25 Theopistus, Vita Dioscuri 275.

26 Tamże 275. 
cych biskupów stwierdził, iż wypowiadane przez nich groźby i wulgaryzmy pod adresem Dioskura nie przystają osobom duchownym ${ }^{27}$.

Tak jak wspominaliśmy powyżej, mimo nalegań Euzebiusza, biskupa Doryleum, Dioskurowi nie postawiono w Chalcedonie zarzutu herezji ${ }^{28}$, sprawa bowiem zdefiniowania natury Chrystusa nazbyt jeszcze dzieliła zebranych tam biskupów, a poza tym tak brzmiący zarzut należałoby postawić wielu obradującym w Chalcedonie duchownym. A i sam Dioskur podejmując obronę swych poglądów chrystologicznych stwierdzał, iż nie są one na Wschodzie nowością, a już na pewno nie herezją, skoro były już tam głoszone przez Atanazego, Grzegorza z Nazjanzu oraz Cyryla ${ }^{29}$. Broniąc się zaś przed zarzutami o poczynione bezprawie w Efezie w 449 r., Dioskur stwierdził, iż w czasie obrad II Soboru Efeskiego postępował on wedle wskazówek otrzymanych od cesarza Teodozjusza II, przez cały czas kontaktując się również z jego przedstawicielami, przysłuchującymi się obradom zgromadzenia ${ }^{30}$. Dla potwierdzenia swego twierdzenia Dioskur żądał również przeprowadzenia konfrontacji z dostojnikami cesarskimi, którzy, przed jak również w czasie trwania obrad soboru w Efezie w 449 r., pośredniczyli między nim a cesarzem ${ }^{31}$. Apel pozostał oczywiście bez echa. Poza tym także, jak to stwierdził Dioskur, podjęte w 449 roku w Efezie decyzje potwierdzili również inni biskupi, jak chociażby Juwenalis, biskup Jerozolimy czy Talasius, biskup Cezarei Kapadockiej ${ }^{32}$.

Wraz z kilkoma biskupami Dioskur nie uczestniczył już w dalszych obradach zgromadzenia i czekał tylko w napięciu na wieści z sali obrad, jakie przynosili im posłańcy. I to właśnie odmowa przybycia przed obradujące zgromadzenie, po trzykrotnym wezwaniu, było powodem zasądzenia depozycji aleksandryjskiego patriarchy ${ }^{33}$. Dioskur wzywany przed sądzące go zgromadzenie wymawiał się tym, iż przybycie uniemożliwiają mu strażnicy pilnujący budynku, w którym zatrzymał się na czas soboru, następnie zaś domagał się uczestniczenia w obradach również komisarzy cesarskich oraz sprzymierzonych z nim, jak mu się jeszcze wydawało, biskupów, za trzecim zaś razem wymówił się złym stanem zdrowia ${ }^{34}$.

Wedle relacji Theopista, kiedy posłaniec przyniósł wieści o przyjęciu przez sobór Tomosu Leona, jak również depozycji oraz degradacji patriar-

27 Por. ACO II 1, 1, s. 69-70.

28 Por. ACO II 1, 2, s. 9. Jeszcze dalej szły żądania wysłanników biskupa rzymskiego Leona, którzy domagali się wykluczenia Dioskura z obrad soboru, w przeciwnym razie grozili opuszczeniem soboru, por. ACO II 3, 1, s. 40; 5; Evagrius, HE II 4. zob. także Horn, Petrou Kathedra, s. 147.

${ }^{29}$ Por. ACO II 1, 1, s. 117.

30 Por. De Vries, Das Konzil von Ephesus, s. 383.

${ }^{31}$ Por. ACO II 1, 1, s. 72; II 1, 2, s. 12-13; Evagrius, HE II 18.

32 Por. ACO II 1, 1, s. 53.

${ }^{33}$ Por. ACO II 1, 2, s. 15-24; zob. także Ritter, Patristische Anmerkungen, s. 270; Camelot, Ephesus, s. 143 nn.

${ }^{34}$ Por. ACO II 1, 2, s. 13; Michael Syriacus, Chronicon II 54-55. 
chy $^{35}$, Dioskur miał tylko zapytać, czy pod wyrokiem podpisał się także Juwenalis, kiedy zaś usłyszał, że tak, wówczas zamilkł. Wspomniane zaś powyżej cesarskie niezdecydowanie, co do losów Dioskura, poświadczają również okoliczności głosowania nad jego depozycją, a mianowicie fakt, iż odbyło się ono pod nieobecność cesarskich komisarzy (którzy kto wie, być może wtedy jeszcze nie dopuściliby do obalenia patriarchy ${ }^{36}$ ) i co nie mniej ważne, jak zauważa S.O. Horn, poinformowany o decyzji soboru cesarz Marcjan przez kilka godzin ociągał się z potwierdzeniem zasądzonej depozycji Dioskura ${ }^{37}$. Pod decyzją składająca go z urzędu podpisało się trzystu ośmiu biskupów ${ }^{38}$. Jak czytamy u Theopista, wynik głosowania nad wnioskiem o depozycję Dioskura w Chalcedonie, miał zostać przyjęty przez adwersarzy patriarchy wybuchem euforii ${ }^{39}$. Co ciekawe w listach biskupów zgromadzonych w Chalcedonie, informujących cesarza $^{40}$ oraz biskupa rzymskiego Leona ${ }^{41}$ o przyczynach zasądzenia depozycji Dioskura, nie wspomina się nawet słowem o tumultach, do jakich to, jak utrzymywali niektórzy, z inspiracji patriarchy miało dojść w sali obrad efeskiego latrocinium po zasądzeniu depozycji Flawiana ${ }^{42}$.

W piśmie informującym cesarza Marcjana o depozycji Dioskura biskupi stwierdzają, iz patriarcha został zdeponowany między innymi za przywrócenie Eutychesa na urząd archimadryty ${ }^{43}$, co jest jednak dość nielogicznym zarzutem. O unieważnieniu depozycji Eutychesa w Efezie w 449 r. nie zadecydował przecież sam Dioskur, lecz większość dostojników kościelnych, którzy w Chalcedonie opowiedzieli się przeciw aleksandryjskiemu patriarsze. Tak jak przystano na wykorzystanie jako zarzutu wątpliwego rozwiązania w sprawie Eutychesa, tak już nie było w Chalcedonie mowy o zaaprobowaniu stanowiska Leona, który domagał się, by obradujący tam biskupi uznali za samowolne zwołanie II Soboru Efeskiego przez Dioskura, samowolne, gdyż odbyło się

${ }^{35}$ Por. Evagrius, HE II 4.

${ }^{36}$ Por. Camelot, Ephesus, s. 143nn; Horn, Petrou Kathedra, s. 188.

37 Por. Horn, Petrou Kathedra, s. 202.

${ }^{38}$ Por. ACO II 3, 2, s. 46-71. W greckim teście Akt widnieją jedynie 252 podpisy; zob. także Camelot, Ephesus, s. 143-144.

${ }^{39}$ Por. Theopistus, Vita Dioscuri 275. W trakcie obrad Soboru Chalcedońskiego trony biskupie odebrano również pięciu sojusznikom Dioskura, a mianowicie Juwenalisowi - biskupowi Jerozolimy, Talazjuszowi - biskupowi Cezarei Kapadockiej, Euzebiuszowi - „biskupowi Armenii" (względnie Euzebiuszowi - biskupowi Ancyry, jak to czytamy w ACO), Eustacjuszowi biskupowi Berytos oraz Bazylemu - biskupowi Seleucji Izauryjskiej. Na polecenie cesarza Marcjana w trakcie czwartej sesji soboru zostali oni jednak przywróceni do godności biskupich, a po zakończeniu obrad powrócili do swych siedzib, por. ACO II 1, 1, s. 190-195; Evagrius, HE II 4; zob. także Honigmann, Juvenal of Jerusalem, s. 242-243.

${ }^{40}$ Por. ACO II 3, 2, s. 83; II 1, 2, s. 41nn; zob. także, Ephesus, s. 145.

${ }^{41}$ Por. ACO II 1, 3, s. 116-118.

${ }^{42}$ Por. ACO II 1, 3, s. 121-122.

${ }^{43}$ Por. ACO II 3, 2, s. 83; zob. także De Vries, Das Konzil von Ephesus, s. 379; Horn, Petrou Kathedra, s. 196. 
ono bez zgody biskupa Leona, co jak ujął wysłannik Kościoła rzymskiego, „nigdy wcześniej nie miało miejsca i już nigdy więcej nie powinno się wydarzyć" ${ }^{4}$. Takie stanowisko było oczywiście niedorzeczne dla zebranych i zostało zignorowane przede wszystkim przez przysłuchujących się obradom cesarskich komisarzy. Sens zarzutu, jaki delegacja rzymska chciała postawić Dioskurowi, budził również wątpliwości u historyków katolickich, którzy wskazywali na jego bezzasadność w 449 r., bowiem sobór do Efezu zwołał przecież cesarz Teodozjusz II, a poza tym także poprzednie sobory (zwoływane również przez panujących) były, co oczywiste, zwoływane bez konsultacji w tej mierze z biskupami Rzymu. Już samo pojawienie się tego zarzutu i próba jego przeforsowania w Chalcedonie dobitnie świadczą o tym, iz Leon dostrzegł wówczas okazję do narzucenia swego prymatu Kościołom wschodnim. Ale nawet zawirowania wokół sprawy Dioskura nie stwarzały okazji dla realizacji aż tak ambitnego przedsięwzięcia $^{45}$.

Warto jeszcze kilka słów poświęcić dalszym losom zdeponowanego w $451 \mathrm{r}$. Dioskura $^{46}$. Obalonego wskutek zmiany polityki kościelnej państwa patriarchę $^{47}$ wywieziono najpierw do Kyzikos, gdzie najpewniej oczekiwał on wyznaczenia miejsca zsyłki. Następnie trafił do Heraklei Pontyjskiej, potem zaś, w nieznanych nam okolicznościach, został przewieziony do paflagońskiej Gangry, a następnie do Chersonezu ${ }^{48}$.

${ }^{44}$ Por. ACO II 1, 1, s. 65.

45 Mało tego, że uznano za mrzonki dążenie biskupa rzymskiego do narzucenia swego rzeczywistego (a nie honorowego) prymatu Kościołom Wschodnim, to jeszcze Leonowi dostał się wówczas przysłowiowy ,prztyczek w nos” poprzez uchwalenie w Chalcedonie kanonu 28, wynoszącego biskupa Konstantynopola do rangi równej Kościołowi Rzymskiemu, por. Evagrius, HE II 4; zob. także Camelot, Ephesus, s. 185nn; G. Dagron, Naissance d'une capitale. Constantinople et ses institutions de 330 a 451, Paris 1974, 482; A. de Halleux, Le vingt-huitième canon de Chalcédoine, StPatr 19 (1989) 28-36; Wipszycka, Kościót, s. 242-245. Uchwalenie w Chalcedonie kanonu 28 skutkowało między innymi zwłoką w potwierdzeniu przez biskupa Leona innych postanowień, jakie zapadły tam w 451 r., a w tej sprawie zmuszony był interweniować na dworze biskupa rzymskiego zaniepokojony tym faktem sam cesarz Marcjan, por. ACO II 1, 2, s. 61.

${ }^{46}$ Po obaleniu Dioskura przedmiotem troski biskupów obradujących w Chalcedonie było również zabezpieczenie stanu majątkowego osieroconego biskupstwa aleksandryjskiego. W piśmie adresowanym przez nich do „Duchowieństwa Kościoła Aleksandryjskiego obecnego w Chalcedonie”, obradujący tam biskupi zaapelowali o to, by adresaci mieli „na uwadze stan wszelkich dóbr" tamtejszego biskupstwa i by przekazali ich spis temu, ,kimkolwiek by on był”, który z „,woli Bożej” oraz za pozwoleniem ,najpobożniejszych i miłujących Boga cesarzy” zostanie ordynowany następcą Dioskura, por. ACO II 3, 2, s. 344. Obalonego zaś w Chalcedonie Dioskura zastąpił Proterios, jeden z prezbiterów Kościoła Aleksandryjskiego, por. Evagrius, HE II 5.

47 Por. Evagrius, HE II 4; Theopistus, Vita Dioscuri 272; Theophanes, Chronographia AM 5944; zob. także Haase, Patriarch Dioscur, s. 303.

48 Por. Evagrius, HE II 5; Zacharias, HE III 2; IV 9, 11; Liberatus, Breviarium 14; Theophanes, Chronographia AM 5944; Extraits de Timothée Aelure, PO 13, 210; Theopistus, Vita Dioscuri 287. Sewer (Refutation d'Eutychius, PO 3, 181), pisze o Gangrze jako o miejscu położonym ,,w kraju barbarzyńców”, anonimowy zaś autor Historii patriarchów Kościoła koptyjskiego 
Biograf aleksandryjskiego patriarchy, Theopist, przekazał nam również nieco informacji na temat warunków, w jakich przyszło Dioskurowi znosić wygnanie. Kiedy więc patriarcha przybył do Gangry, spotkał się tam z chłodnym przyjęciem miejscowego biskupa, który sakrę biskupią otrzymał rzekomo „,Z rąk Nestoriusza” i jak stwierdza to Theopist, jedyne, co mogło spotkać tam Dioskura, to ciągłe zniewagi i poniżanie ze strony owego heretyka, który w taki sposób odpłacał się za „obalenie swego mistrza”49. Nie można oczywiście wykluczyć, iż sytuacja taka rzeczywiście mogła mieć miejsce, choć z drugiej strony wydaje się być ona spreparowana na potrzeby monofizyckiej propagandy, by wykazać, iż Dioskur padł ofiarą spisku nestorian, którzy powrócili do łask za panowania nowego bezbożnego cesarza Marcjana. Złe warunki mieszkaniowe oraz zgryzota szybko przyprawiły patriarchę o chorobę. Niedostatek zaś rzeczy koniecznych do życia na wygnaniu zmusił towarzyszy poniewierki Dioskura do wyjścia na ulicę i parania się żebractwem. Duchownych w potrzebie wsparł sporą sumą pieniężną przebywający wówczas w Gangrze pewien kupiec aleksandryjski. Dioskur jednak, ku irytacji swych towarzyszy niedoli, postanowił pieniądze te rozdać pomiędzy miejscowych biedaków (jakże by inaczej!), nie był bowiem pewien, jak twierdził, czy pieniądze te zostały zarobione w uczciwy sposób ${ }^{50}$. Przebywając na wygnaniu Dioskur miał również oddać się działalności pisarskiej. Dowiedziawszy się od odwiedzającego go archidiakona Pafnucego z Tabennisi o męczeńskiej śmierci jednego ze swych stronników - Makarego, biskupa Tkôw, przystąpił on do spisywania panegiryku na jego cześć ${ }^{51}$. Pafnucy miał również przywieźć Dioskurowi obfitą jałmużnę od wiernych Kościoła Aleksandryjskiego, co z kolei wywołało podejrzenia u biskupa Gangry, czy aby nie są to środki zagrabione z tamtejszego biskupstwa $^{52}$. Jako, iz miejscowy biskup, wspierany w swym zacietrzewieniu wobec

Aleksandrii (s. 444), pisze o „wyspie Gangrze”; zob. także Haase, Altchristliche Kirchengeschichte, s. 305 i 313; Ph. Blaudeau, Timothée Aulure et la direction ecclésiastique de l'empire post-chalcédonien, REB 54 (1996) 110. Anonimowy i w tym przypadku również niedoinformowany biograf mnicha Barsaumy podaje, iz Dioskura zesłano na jedną z wysp na Zachodzie, por. Vita Barsaumi, ROC 14 (1909) 139-142.

${ }^{49}$ Por. Theopistus, Vita Dioscuri 287. Jak czytamy pod datą 7 września w Synaxarium oder Heiligenkalender der koptischen Kirche (aus Arabischen übersetzt von F. Wüstenfeld, Gotha 1879, 14 i 89), sytuacja taka trwała do czasu, aż Dioskur w miejscu swej zsyłki zaczął czynić cuda.

${ }^{50}$ Por. Theopistus, Vita Dioscuri 290.

51 Por. tamże 304 i 307.

52 Por. tamże 292. Przebywający na wygnaniu Dioskur utrzymywał również nadal kontakt korespondencyjny ze swymi stronnikami. Z relacji Theopista wynika, iż patriarcha wysyłał stamtąd listy do mnichów klasztoru Henaton oraz do bliżej nieznanego nam biskupa Sekundina, namawiając swych adresatów do trwania w oporze wobec postanowień Soboru Chalcedońskiego, por. tamże 287. Przebywającego na wygnaniu Dioskura odwiedzali również jego stronnicy, por. tamże 304. W kontakcie korespondencyjnym z przebywającym na wygnaniu Dioskurem pozostawał też Piotr Iberyjczyk, monofizycki biskup palestyńskiej Majumy, por. Joannes Rufus, évêque de Maïouma, Plérophories, PO 8, ed. et trad. F. Nau, Paris 1911, 365. 
Dioskura przez Proteriosa Aleksandryjskiego, coraz bardziej uprzykrzał wygnańcowi pobyt (co jak akcentuje autor Żywota, nie było przecież wolą panującego wówczas cesarza Marcjana) przebywający z nim na wygnaniu archidiakon Piotr poinformował o tym dwór cesarski, który miał błyskawicznie zareagować na te doniesienia, przez co też resztę swej poniewierki Dioskur spędził już we względnym spokoju ${ }^{53}$.

Patriarcha zżerany zgryzotą zmarł na wygnaniu już w 454 r., a jego śmierć w miejscu zsyłki musiała w wymiernym stopniu przyczynić się do propagowania kultu pośmiertnego zesłańca ${ }^{54}$. Relikwie zaś zmarłego na wygnaniu Dioskura zostały sprowadzone do Aleksandrii przez Tymoteusza Ailurosa ${ }^{55}$.

Reasumując powyższe rozważania stwierdzić należy, iż obalenia patriarchy aleksandryjskiego Dioskura należy do przełomowych wydarzeń, mających wpływ na kształtowanie się doktrynalnego oblicza późnoantycznego chrześcijaństwa. W opinii wielu ówczesnych oficjeli, zarówno z otoczenia cesarza jak też spośród wyższego duchowieństwa, to właśnie po śmierci Teodozjusza II zaistniał dogodny moment na pozbycia się potężnego patriarchy i umniejszenie znaczenia Kościoła Aleksandryjskiego, który od kilkudziesięciu lat trząsł Kościołem na Wschodzie, obalając jednych biskupów, na ich miejsce ustanawiając innych, uległych sobie duchownych. Obalenie potężnego patriarchy tylko pozornie uspokoiło nastroje panujące w Kościołach Wschodu, a cesarz Marcjan musiał poświęcić jeszcze wiele uwagi ugruntowując w tamtejszych Kościołach porządek chalcedoński ${ }^{56}$.

\section{THE FALL OF DIOSCUROS OF ALEXANDRIA}

(Summary)

The overthrow of patriarch Dioscuros appertains to the breakthrough events, which influenced the doctrinal countenance of Late Antique Christianity. Despite the fact that the decision to deprive the patriarch of the throne remained solely

53 Por. Theopistus, Vita Dioscuri 295.

${ }^{54}$ Niemniej, jak czytamy u Theopista, Dioskur miał czynić cuda jeszcze za życia w miejscu swej zsyłki, por. Theopistus, Vita Dioscuri 295 (uzdrowienie chorej ręki; uzdrowienie dwóch żydowskich kupców, którzy następnie przyjęli chrzest, por. tamże 300). Cuda miały rzekomo miejsce również w Egipcie. Uzdrowicielską moc miały posiadać nawet sandały patriarchy Dioskura, które założone na stopy przyczyniały się do uzdrawiania chorych kończyn, por. tamże 299.

55 Por. Zacharias Rhetor, HE V 4.

${ }^{56}$ W 455 r. cesarz Marcjan wydał chociażby reskrypt, w którym ogłosił, by żaden biskup nie ośmielił się występować przeciw postanowieniom w sprawach wiary, jakie przyjęto w Chalcedonie. Tym zaś, którzy będą tak czynić cesarz zagroził wygnaniem, por. CJ I 5, 8, 9; 10. 
political, the very depositional proceedings were commenced on the charge of wrongdoings committed by Dioscuros prior to and in the course of the second Ephesian Council. During the Chalcedonian Council there were also four Alexandrians who maintained accusations against the patriarch, those being: two deacons (Theodoros and Ischyrionis), presbyter Athanasius and Sophronios, of whom we possess little knowledge. It was proved, however, that even the substantial charges did not destine Dioscuros to be overthrown as much as did his refusal to attend the council. The overthrown patriarch was exiled and therein died in 454. His relics were translated to Alexandria during the reign of Tymotheus Ailuros. 